\title{
EL NIÑO DE LA BOLA Y LA FISIOLOGÍA DE LA NOVELA DECIMONÓNICA (II) *
}

\author{
Eva F. FLORENSA \\ University of Pennsylvania
}

\section{La "Novela Contemporánea" y el análisis de caracteres}

Cuando Don Trajano Mirabel está relatando a Luisita lo que nosotros hemos leído en resumen de la mano de Leopoldo Alas, la esposa del moratinista -al oír la palabra "adulterio"-_ se exalta:

¡Mirabel!... ¡yo no te he oído nunca hablar así! - interrumpió doña Tecla-. ¡Esto pasa ya de castaño oscuro! (Alarcón, 1880, pág. 183).

Y el seguidor de Moratín le replica:

Porque nunca he tenido que hablarte de psicología ni de fisiología... -respondió el académico-. Pero la marquesa me comprende... (ibíd.).

¡En 1840 (momento en que se desarrolla la acción de la obra) un moratiniano afirma estar haciendo "estudios" (ibíd., pág. 184) de psicología y de fisiología! ¿Es éste un anacronismo por parte de Don Pedro A. de Alarcón? No.

El historial clínico de Manuel Venegas y de Soledad son — sin lugar a dudas- dos perfectas construcciones psicológicas pormenorizadas. En este hecho, no se separa el novelista andaluz de otros trabajos análogos que hicieran en 1881 Don Benito Pérez Galdós alrededor de Isidora Rufete (La deshereda$d a$ ) o en 1883-1885 Leopoldo Alas con su heroína, Doña Ana Ozores ( La Regenta), estudios psicológicos —estos últimos—que se han venido considerando por parte de la crítica como naturalistas o, por lo menos, indudablemente realistas. En tales análisis, los períodos de la infancia y de la juventud son determinantes de la personalidad que el individuo poseerá en su madurez.

* Continuación de lo publicado en nuestro número anterior. 
Leopoldo Alas reconocía esta ley incluso cuando diseccionaba el carácter de alguno de sus contemporáneos; así, en su folleto titulado Benito Pérez Galdós, afirmó: "Soy de los que opinan que en la historia de los hombres la de su infancia y adolescencia importa mucho" (Alas, 1889, pág. 11). Con este criterio, era lógico que, en La Regenta, "Clarín" explicase durante hojas y hojas el origen social de la madre de Ana, la procedencia y el carácter de su padre, la educación liberal que éste le dio, la pronta orfandad de la niña, y el nuevo tipo de instrucción a que la sometieron sus tías, las nuevas tutoras. Para Leopoldo Alas, todas estas circunstancias que acabo de enumerar determinaron física y psicológicamente a la Regenta.

Un historial clínico realista-naturalista se complementaba con otro condicionante básico de la personalidad, la herencia. La locura de Isidora Rufete tiene sus precedentes en su padre y su hermano; las elucubraciones poético-espirituales de Ana Ozores hunden sus raíces, según sus propias tías, en el legado genético de su madre ' . Don Pedro A. de Alarcón coincide con Leopoldo Alas y Benito Pérez Galdós, pues, en El Niño de la Bola, se afirma expresamente este tipo de determinismo en la figura de Manuel Venegas al decir de él que su progenitor fue "descendiente, según dicen, de príncipes moros, cuya pícara sangre se le conoce bien a este chico en medio de sus buenos sentimientos" (Alarcón, 1880, pág. 25). De su padre hereda Manuel su heroísmo ("El alma heroica que heredara de su padre" [ibíd., págs. 102-103]), la fantasía ("fogosa y pertinaz imaginación" [ibíd. pág. 72]) y su destino trágico. Así pues, la personalidad del joven Venegas debe incluir también para su total cuadro clínico el factor de la herencia.

Conviene detenerse aquí para valorar la significación del análisis de psicología y de físiología que se realiza en torno a Soledad y a Manuel Venegas en El Niño de la Bola. La novela, como sabemos, se publicó en 1880. A juzgar por la importancia otorgada a la herencia y las circunstancias de la niñez y juventud de los dos protagonistas de la obra, la técnica de construcción de personajes de Don Pedro Antonio se emparenta directamente con la de Pérez Galdós y Alas. ¿Significa esto que el estudio de caracteres en la novela es un rasgo del realismo de la segunda mitad del siglo XIX?; dicho en otros términos, ¿la reconstrucción detallado-realista de una personalidad es una técnica propia de la nueva manera de novelar iniciada en España por Don Benito Pérez Galdós hacia 1870 ?

1. A esta conclusión llegan las tías a través de las informaciones que les ha ido aportando Doña Camila, la institutriz de Ana durante su infancia. Por su parte, el narrador es muy consciente de la importancia que las circunstancias de su niñez han tenido en la joven Ozores, pero parece dudar de la credibilidad de la interpretación determinista-hereditaria de Doña Camila y las tías (Alas, 1981, vol. I, págs. 193 y 232). 
Los más destacados críticos de la centuria pasada ("Clarín”, Rafael Altamira, Armando Palacio Valdés, etc.) contestaron afirmativamente a mis preguntas anteriores. Para ellos, el análisis de caracteres - un elemento que entendían como básico para toda buena novela - fue una innovación posterior a La Gloriosa (1868). Los más tradicionalistas (Benito Pérez Galdós, Emilia Pardo Bazán, etc.) lo retrotrajeron a Böhl de Faber y Mesonero Romanos. La dirección crítica que triunfó fue la de los primeros y, desde entonces, la novela contemporánea española comienza con La Gloriosa y, concretamente, con Don Benito Pérez Galdós.

José Alcalá Galiano, en su artículo "La fontana de oro", afirmaba lo siguiente, en 1871, sobre el arte de novelar de Don Benito: "Sólo la novela contemporánea puede, en efecto, hacer el análisis del alma humana" (Alcalá Galiano, 1871, pág. 152). También Armando Palacio Valdés, en artículo de 1878 titulado "D. Benito Pérez Galdós", reconoce en éste la calidad de pintor del estado mental o psicológico de sus personajes, hablando de que le caracteriza "un realismo espiritual e interior" y de que usa su pluma para "pintar al detalle y con admirable penetración, los más íntimos, los más vagos y confusos sentimientos del espíritu" (Palacio Valdés, 1878b, pág. 338).

Don Pedro A. de Alarcón, sin embargo, no estaba de acuerdo con aquellos de sus contemporáneos que iniciaban todo con La Gloriosa, e, incluso, iba más allá en la búsqueda de los orígenes del realismo que Doña Emilia y Don Benito. El análisis de caracteres - todos, librepensadores y críticos tradicionalistas, están de acuerdo- es el pilar fundamental del realismo en la novela. En El Niño de la Bola, una narración que sitúa su tiempo histórico en el año de 1840, hay un personaje, seguidor de Leandro Fernández de Moratín en lo artístico, afrancesado en su juventud política, y miembro de una sociedad secreta llamada "Jovellanos" (Alarcón, 1880, pág. 156), que realiza con la personalidad de la "Dolorosa" lo que él llama "estudios" (ibíd., pág. 184) "de psicología" y "de fisiología" (ibíd., pág. 183). Estas "autopsias morales"² de Soledad, ¿son un anacronismo por parte de Alarcón? Ni mucho menos y, antes, todo lo contrario. Don Pedro Antonio sabía muy bien que los "estudios" "de psicología" y "de fisiología" existieron ya en la época de la niñez y juventud de Don Trajano Mirabel, es decir, hacia 1780.

En 1978, Rusell P. Sebold demostró en el "Prólogo" a su edición de $E l$ señorito mimado. La señorita malcriada, de Tomás de Iriarte, y en el artículo "Historia clínica de Clara: La mogigata de Moratín", que estos dos autores habían dibujado sus personajes siguiendo una idea propia del siglo ilustrado: el

2. Estos términos son una variante introducida, sólo, en la revisión que D. Pedro Antonio realizara de El Niño de la Bola para sus Obras (Alarcón, 1884, pág. 186). No aparecen en las tres primeras ediciones de la novela. 
medio en que se vive la niñez y juventud (familia y educación) condiciona la personalidad del individuo en su madurez ${ }^{3}$. Don Mariano, en El señorito mimado (1787), es un joven superficial y de pésima conducta por causa de la ineptitud de su madre como educadora; Doña Pepita, en La señorita malcriada (1788), es una petimetra que refleja en su persona los defectos nocivos de un padre juerguista y alocado; finalmente, en La mogigata (1791), la hipocresía de la hija no tiene otra causa que la gran hipocresía de su progenitor. Por otra parte, Sebold señalaba también en sus trabajos cómo en todas estas comedias existe un personaje alienista que descubre al público el origen de la enfermedad psicológica de los jóvenes (Don Cristóbal, Doña Clara y Don Luis, en El señorito mimado, La señorita malcriada y La mogigata, respectivamente).

En El Niño de la Bola, Don Trajano, educado en los principios de la Ilustración, era el único que podía comprender y analizar la psicología de la "Dolorosa". Él es el personaje alienista de nuestra novela. Su filiación moratiniana, además, nos informa de que Don Pedro Antonio tenía del pasado literario español un mejor conocimiento que José Alcalá Galiano, Leopoldo Alas o Armando Palacio Valdés al reconocer que el estudio pormenorizado de los caracteres va muchísimo más allá de la novela nacida con La Gloriosa. Este hecho histórico-literario permite dibujar una línea que comunica directamente el Realismo de la segunda mitad del siglo XIX con las bases intelectuales y la literatura del siglo XVIII: el análisis físico-psíquico de los personajes literarios no es una innovación de la novela decimonónica (ni de la primera ni de la segunda mitad del siglo XIX), es un resto en este siglo de las letras ilustradas. Tal aserción destruye la "novedad" de uno de los pilares básicos de la novela realista (el estudio de caracteres) en favor de un retroceso de sus orígenes en más de cien años.

Pero, ¿no pudo acontecer que, tras la literatura ilustrada, se perdiesen los análisis físico-psíquicos de los personajes de manera que en la novela realista éstos sí fueran una novedad?

José Alcalá Galiano, en su artículo anteriormente aludido, parecía sugerir una respuesta positiva a esta pregunta cuando, en relación a la novela histórica de la primera mitad del siglo XIX, afirmó: "y cuyos personajes no nos ofrecen más que la exterioridad de sus actos sin que podamos penetrar los recónditos senos de su conciencia" (op. cit., pág. 152). Sin embargo, otro artículo de Armando Palacio Valdés, "D. Francisco Navarro Villoslada”, permite puntualizar

3. Russell P. Sebold demuestra esta base intelectual ilustrada, no sólo en el Prólogo a $E l$ señorito mimado. La señorita malcriada y en "Historia clínica de Clara: La mogigata de Moratín", sino también en la producción novelística dieciochesca, concretamente en su estudio preliminar a Fray Gerundio de Campazas de José Francisco de Isla. 
lo que, en boca de Alcalá Galiano, se interpretaba como una negación del análisis de caracteres en la novela histórica romántica. Comienza el crítico afirmando que "la novela histórica" falsea la "descripción más o menos fiel de [...] sentimientos de un período histórico" (Palacio Valdés, 1878a, pág. 712) porque "insensiblemente, sin que el artista lo perciba, y a despecho de todos sus escrúpulos y pruritos de veracidad, se introduce en la obra el acento moderno y se enseñorea de ella" (ibíd., pág. 713). Con gran humor dice Don Armando que, en la novelística histórica, el mundo psicológico subyacente bajo el medievo o la época de los austrias es el romántico trasnochado. Es decir, Palacio Valdés rechaza aquel tipo de novela en que, "al penetrar en una sala gótica" (ibíd.), halla allí "al vecino del cuarto tercero" que es "persona muy honrada, de continente grave y hasta cierto punto melancólico" (ibíd.). El crítico niega esta forma novelística romántica ("la novela arqueológica no es viable como género literario" [ibid.]) por cuanto no guarda decoro entre el momento histórico que describe y el universo psíquico de los personajes que lo pueblan. Sin lugar a duda, para Palacio Valdés, éste era un grave atentado contra la verdad o "realismo", pero él mismo (cuando se preocupaba únicamente de lo literario, y no caía en sus prejuicios políticos de pensador liberal) nunca pudo considerarlo una negación del análisis de caracteres por parte de la novela histórica. A confirmar mi último aserto acude otro de sus artículos dedicado a "D. Manuel Fernández y González". En él, incluye "la pintura de los caracteres" como uno de los componentes, junto a "la descripción de costumbres" y "la verosimilitud de la fábula" (Palacio Valdés, 1878c, pág. 661), de la novela histórica. Además, comentando la manera de novelar de Fernández y González, acaba diciendo Don Armando que éste "es más realista de la Edad Media que su maestro Walter Scott" (ibíd., pág. 660. Subrayado de Palacio Valdés) porque mientras el último dibujaba a su Ivanhoe "con ese tinte suave y melancólico" (ibíd.), el novelista español "penetra por la coraza damasquina y la recia cota de malla, y sorprende los sentimientos de aquellos corazones tan rudos e independientes" (ibid.).

Así pues, toda "novela arqueológica" poseía estudio de caracteres, aunque éste, comparado con su marco histórico, era corrientemente anti-"realista". Sólo unos pocos (Fernández y González, según Armando Palacio Valdés) lograron el éxito en la ardua tarea de reconstrucción de la novela histórica, los más cometieron el anacronismo de dotar con un perfecto estudio de la psique romántica a hombres que vestían "coraza damasquina" y "recia cota de malla". Es decir, la novela del Romanticismo, desde el punto de vista de la psicología de sus personajes, era "realista" en relación al universo psíquico de la época en que la escribían sus autores, pero totalmente anti-“realista" (verbigracia, "idealista", según término de la época) con respecto al contenido mental del momento histórico en que ocurría la acción de la obra. Conscientes de este 
problema, los hombres del Realismo decidieron abandonar el pasado y acudir al presente, del cual podían escudriñar su marco histórico y sus psicologías sin anacronismo alguno. Así Armando Palacio Valdés afirmaba que "todas las personas de cierta categoría literaria están conformes en que ... los sentimientos que se pinten, han de ser ... los sentimientos contemporáneos" y que cuando se quisiera conocer los de otra época se acudiese a las crónicas, a las memorias o a las letras de aquel momento, nunca a las producciones novelísticas del Romanticismo (Palacio Valdés, 1878a, pág. 173)

No sólo coinciden las comedias de costumbres, la novela histórica y la novela de la segunda mitad del siglo XIX en el estudio de caracteres, sino también en la base filosófico-científica en que éste se apoyaba. Hemos visto cómo El señorito mimado, La señorita malcriada o La mogigata respondían, en la elaboración de la psique de sus protagonistas, a la idea dieciochesca de que el medio configura la personalidad de un individuo. Vimos cómo éste era también el sustento ideológico de la construcción de los caracteres en La desheredada, La Regenta o en El Niño de la Bola. Mi tesis quedaría incompleta si no señalase la continuidad de este principio en la novela histórica de la primera mitad del siglo XIX. De ser esto posible, aparece en la historia de la literatura un nuevo lazo que une las letras del XVIII con las de su inmediato próximo, y que -destruyendo la incomprensión de la crítica del siglo XX y evidenciando el manejo interpretativo que algunos de los críticos posteriores a La Gloriosa hicieron de su pasado inmediato- acerca estrechamente la novela histórica romántica a la novela realista de la segunda mitad del XIX.

A pesar de que la construcción de caracteres apenas se ha estudiado en la novelística del Romanticismo, contamos, sin embargo, con unas breves anotaciones de Russell P. Sebold que abren el inmenso campo existente en la novela romántica para aquéllos interesados en este tipo de análisis. En un corto artículo de 1988, el ilustre filólogo norteamericano apunta la relación presente entre el estudio de caracteres de la novela romántica y el del Realismo. Hablando de Kerima, la protagonista de El moro expósito (1834), novela histórica en verso del Duque de Rivas, dice que el "estudio clínico" realizado sobre ella "se anticipa a los análisis patológicos de personajes femeninos de

4. Las mismas ideas había expresado treinta años antes Ramón de Navarrete. Definía la novela histórica como "una narración más o menos fiel, más o menos exacta, de sucesos pretéritos" (Navarrete, 1847, pág. 83), pero no consideraba que ella cumpliese con la que a su juicio era la finalidad de toda novela ("ilustrar a la generación presente en lo que es relativo a sus vicios propios, a sus instintos y a las leyes que la mueven y la gobiernan" (ibíd.). Según Navarrete, dichos objetivos sólo se alcanzarían si nuestros novelistas imitaban lo que se hizo en el pasado ("Casi todos los escritores antiguos, al escoger época para sus obras, hacíanlo en la suya propia" (ibid.). Por lo tanto, concluye el crítico que, entre las modalidades novelísticas discutidas, los hombres de letras del momento deben "preferir la novela contemporánea [v. g., "novela de costumbres contemporáneas"] a la novela histórica" (ibid.). 
novelas decimonónicas posteriores, como Madame Bovary y La Regenta" (Sebold, 1988, pág. 72). El profesor norteamericáno no olvida mencionar que éste no es un caso aislado en la primera mitad del siglo XIX ya que el mismo tipo de construcción e idea subyace bajo "la historia clínica de la tuberculosis y la ansiedad de separación de Beatriz en El señor de Bembibre (1844) de Enrique Gil y Carrasco" (ibid.). Y, acto seguido, Sebold pasa a desarrollar el análisis del carácter de Kerima que el "alienista", Angel Saavedra, dictamina en El moro expósito: la decisión de la joven, al final de la novela, de profesar está racionalmente explicada y justificada a través de una historia clínica en la que el medio juega un papel determinante ("Su sufrimiento y la imposibilidad de sus amores son de su propia fabricación, bajo la influencia de su medio" [ibíd.]). Estudios del tipo realizado por Russell P. Sebold son un corrosivo de las fronteras que interpretaciones críticas prejuiciosas o desencaminadas han levantado entre las dos modalidades novelísticas del siglo XIX. Más adelante, en el presente artículo, veremos cómo dichos límites en la novela decimonónica caerán casi completamente para permitir el esbozo de un nuevo cuadro de la historia literaria del siglo en donde, antes que ruptura y diferencias entre el Romanticismo y el Realismo, se delinean semejanzas y lazos de continuidad histórica.

\section{La "Novela Contemporánea" y el estudio de costumbres}

A Doña Emilia Pardo Bazán le parecía, en su folleto Pedro Antonio de Alarcón (1891-1892), que la grandeza de El Niño de la Bola radicaba en su "color local andaluz" (Pardo Bazán, 1973, pág. 1397). Dijo la autora al respecto:

Que El Niño de la Bola es novela rara, hermosa, fuerte, bañada de luz meridional, étnica en el sentido más delicado de la palabra ... lo considero probado para todo el que lea ese precioso libro (ibíd., pág. 1396. Subrayado de Doña Emilia).

¿Qué significa que El Niño de la Bola sea una novela "étnica"?

Cada colectividad — pensaban los hombres del Realismo- posee una peculiar forma de pensar y de vivir dependiendo de su pasado histórico y de su sangre. Las artes, afirmaron estos mismos hombres, debían ser expresión y estudio de tal peculiarismo. Doña Emilia, en su folleto ya citado, plasma esta idea en forma definitiva:

No cada nación, sino cada raza de las que el nombre de nación unifica políticamente, sin lograr fundir la misteriosa diversidad y hasta oposición de sus sangres y de sus almas, tiene una poesía característica, modos de sentir, de soñar, de amar y de creer, que se revelan en momentos críticos, con belleza propia, íntima y penetrante. Esa poesía, 
que resplandece con fugitiva luz, el gran artista la sabe condensar en un libro, en un cuadro, en una estrofa (ibid.), págs. 1396-1397).

El concepto "raza" en el siglo XIX no era tan estrecho como el de la actualidad y se refería a todo grupo humano que participaba de unas mismas particularidades histórico-socio-culturales: los habitantes de un determinado territorio, una clase social, una ciudad, los individuos de una misma profesión, etc. Con esta idea de raza y con su compañera (las artes han de expresar dicho peculiarismo étnico) se escribió, por aquel entonces, la mejor literatura de todo el siglo XIX. Émile Zola analizaba en los Rougon-Macquart la "raza" parisina. Don Benito Pérez Galdós, en 1870, aconsejó ${ }^{5}$ que la novela española contemporánea estudiase la "raza" madrileña (Pérez Galdós, 1870, pág. 166). Con su vocabulario krausista y asimilando el concepto "raza" al de "nación", Leopoldo Alas divulgaba también este mismo principio mental. En su fclleto Benito Pérez Galdós dice que el novelista canario, en sus creaciones literarias, tiene la finalidad "de escribir la historia novelesca de nuestra epopeya nacional del presente siglo" (Alas, 1889, pág. 26. Subrayado mío). Para interpretar correctamente a "Clarín" debe saberse que él y otros krausistas entendían la "epopeya" como un vasto panorama literario de las instituciones, las costumbres y la cultura general de un pueblo o colectividad que sirve para definir su carácter. Don Francisco Giner de los Ríos, en 1864, lo expresó así: "Por esto son las epopeyas, al par que inextinguibles tesoros de bellezas inmortales, precioso arsenal de datos para el historiador y como la muestra más espontánea y evidente que da de sí y de su genio un pueblo" (Giner de los Ríos, [1864] 1969, pág. 57). Y voy a hacer mención aquí, para perfilar completamente el alcance de esta idea, que Leopoldo Alas, en Apolo en Pafos (1887), afirma que "la novela es la épica del siglo" (Beser, 1972, pág. 30. Subrayado del autor) y también "un modo de historia de la actualidad" (ibíd., pág. 33).

Como puede verse, los términos que usan estos novelistas y críticos refiriéndose a la descripción realista que la novela hace de "modos de sentir, de soñar, de amar y de creer" de un grupo humano concreto o "raza" son muy variados. Balzac habló de "physiologie" y Émile Zola de "histoire", Doña Emilia Pardo Bazán de "novela étnica", Leopoldo Alas y Francisco Giner de "épica" o "epopeya nacional", sin embargo, todos ellos se referían a lo que genéricamente se calificaba como "la novela moderna de costumbres" (Pérez Galdós, 1870, pág. 167).

5. Pérez Galdós fue aconsejando lo mismo a lo largo de !wa su vida. En dos de sus mejores artículos, ambos de 1897, "La sociedad presente como materia novelable" y "José María de Pereda, escritor" (Pérez Galdós, [1897] 1972, págs. 173-182 y 189-204, respectivamente), el novelista canario reincide en la idea de que la novela debe ser expresión del estado mental y ambiental de la colectividad concreta que el autor estudie.

6. El subtítulo "histoire" ("fisiología") de Les Rougon-Macquart fue utilizado también por Galdós, quien subtituló: "Dos historias de casadas" su Fortunata y Jacinta. 
Si el estudio pormenorizado-realista de caracteres se consideró una de las bases de la recién nacida novela española tras La Gloriosa, el estudio pormenorizado-realista de las costumbres era, según los hombres de la segunda mitad del siglo XIX español, el otro pilar de la nueva novela. Pero, ¿en qué consistía exactamente un análisis minucioso-realista de costumbres?

Los personajes - como instrumentos para la expresión de "modos de sentir, de soñar, de amar y de creer"- se convirtieron en la novela del Realismo en "tipos". Afirmar este hecho no significa suprimir al estudio de caracteres su profundidad, sino todo lo contrario, ya que éstos se construían como directamente determinados por su ámbito vital (herencia, familia y cultura), es decir, por los "modos de sentir, de soñar, de amar y de creer" que les rodeaban. En otros términos, el siglo XIX descubrió que una personalidad - por cuanto se origina condicionada por las circunstancias de su alrededorse convierte en reflejo, y por tanto, símbolo, de ellas. Este es el contenido mental subyacente bajo el concepto "tipo" de la crítica y de la literatura decimonona ${ }^{7}$.

El mismo medio ambiente en que se desarrollaba una personalidad (modos de educar, costumbres familiares, religiosas y sociales, etc.) -por ser éste reflejo realista del momento histórico- era también propia del Costumbrismo. Así pues, Costumbrismo lo era todo para la narrativa novelística del siglo XIX. Lo fue la fiel descripción y análisis de los personajes y de su historia porque, como "tipos", representaban a los hombres del momento con todo su contenido mental y carga histórica. Lo fue también la fiel reproducción de la realidad socio-económica, política y cultural porque ése era el marco en que los individuos del XIX se habían formado y continuaban formándose como personalidades. Costumbrismo, repito, lo fue todo para la narrativa novelística posterior a $\mathrm{La}$ Gloriosa. Esta afirmación (que posiblemente escandalizará a la mayoría de críticos de mi época) no es mía, sin embargo. Luis Vidart, en un estudio sobre Un viaje de novios de Doña Emilia Pardo Bazán que tituló "El naturalismo en el arte literario y la novela de costumbres" (1882), defendía que "la novela de costumbres [es decir, Un viaje de novios], o es naturalista, o no es novela de costumbres" (Vidart, 1882, pág. 190). Al igual que casi todos sus coetáneos, Vidart se refiere a la novela moderna de su época con el término "novela de costumbres contemporáneas" (ibíd., pág. 197). Es más, para él, Realismo y Naturalismo son técnicas científico-literarias o instrumentos para la construcción de una novela, pero no palabras que definan a la vez a éstos y la intención y contenido de una obra novelística (o sea, "el estado de la cultura contemporánea" [ibid.]), palabras que no pueden ser otras que "novela de costumbres".

7. Definía Andueza en 1845: "Tipo es un individuo de la sociedad que representa una clase a la cual convienen costumbres propias que de ningún modo pertenecen a otra alguna [...] en estos tipos está no sólo retratada la figura, sino el alma" (Montesinos, op. cit., pág. 111 ). 
Nadie es capaz de negar que El Niño de la Bola no sea una "novela de costumbres". Para quienes tengan una visión estrecha (a saber, de siglo XX) del Costumbrismo, podemos aducir dos "cuadros" de la obra: los episodios de la "rifa" (Alarcón, 1880, págs. 118-129 y 350-370) y el capítulo titulado "Dos retratos por vía de entremés (capítulo inútil, que pueden dejar de leer los impacientes)" (ibid., págs. 160-171). Para los que hayan comprendido lo que andamos diciendo, será ya claro a esta altura de mi artículo que el estudio de las personalidades de Manuel Venegas y de la "Dolorosa" son Costumbrismo, y que desde luego, en El Niño de la Bola, hay toda una reconstrucción "costumbrista" de una ciudad provinciana de Sierra Morena en el año concreto de 1840. Ello significa que el análisis económico, social, de las tradiciones religiosas, educativas y literarias, de la política, etc. que existen en la novela de Don Pedro Antonio no es más que un "cuadro" (Alarcón, 1880, pág. 6) de los "modos de sentir, de soñar, de amar y de creer" de una urbe andaluza por los años en que triunfaba el Romanticismo.

Acabemos de perfilar la figura de Manuel Venegas como "tipo". Si El Niño de la Bola es una novela "étnica", tal como afirmaba Doña Emilia, entonces el joven debe ser reflejo "costumbrista" ("modos de sentir, de soñar, de amar y de creer" + realismo) de una personalidad arábigo-andaluza ${ }^{8}$.

Don Pedro Antonio inicia su capítulo II del Libro I, "Nuestro héroe", con una descripción pormenorizada de la imagen de Manuel Venegas. Describe su forma de vestir para terminar poniendo de relieve su "atavío semi-andaluz, semi-exótico" (ibíd., pág. 11). A continuación, comienza el retrato de su faz, señalando "sus africanos ojos" (ibíd., pág. 12). Pasa luego Don Pedro Antonio al cabello de Venegas y, algo más tarde, a su "fisionomía" (ibíd.), retratando "un perfil intachable, sirio más bien que griego... y, sobre todo, una barba negra, undosa, de sobrios aunque largos rizos, trasunto fiel de las nobles y celebradas barbas árabes y hebreas (ibíd. Subrayados míos). Sin lugar a dudas, Alarcón era un buen discípulo de Johann Caspar Lavater ${ }^{9}$ (;1741-1801!), quien, a través del estudio de las facciones del rostro, determinaba el carácter o psicología de

8. El siglo XIX concibió a Andalucía y Murcia como pueblos o "razas" moriscos, es decir, afectados por una gran impronta árabe, D. Pedro Antonio a menudo se hizo eco de esta interpretación histórico-determinista. Sobre uno de sus propios parientes dijo: "Eran unos grandes ojos moriscos, llenos de luz y energía [...] Eran los ojos de mi primo, más semítico que jafético" (Alpujarra, V, i). En torno a tío Lucas escribió: "Vamos... Vamos a descambiar, díjole el murciano a don Eugenio, alegrándose mucho de no haberlo asesinado, pero mirándolo todavía con un odio verdaderamente morisco" (El sombrero de ires picos, XXXIII). Fikalmente, en La Pródiga, II, xiii dejó clara la idéntica filiación étnica de andaluces y murcianos: “¡Estos andaluces!... -Murciano, señor conde... -Viene a ser lo mismo".

9. Quienes estén interesados en la "Fisiognomía", en Lavater y en el influjo de aquélla en la literatura europea, pueden acudir a Graeme Tytler, Physiognomy in the European Novel, Faces and Fortunes. 
un individuo. Por medio del análisis "fisiognómico" de Manuel Venegas, Don Pedro Antonio dictamina que el Niño de la Bola es una completa personalidad romántica, no sólo por la educación rusoniana que recibió, sino también porque su "raza" semita le convertía en un campo abonado para que germinara con total éxito la semilla del Romanticismo. La "fisonomía" morisca que dibuja Alarcón va acompañada, pues, de su "psicología" y así el "cuadro" de la personalidad del joven se completa con el análisis de las aportaciones de la sangre árabe en el carácter de Manuel Venegas, romántico por Rousseau y por su raza.

El Niño de la Bola era "descendiente del Profeta Mahoma" (Alarcón, 1880 , pág. 27), tal herencia sanguínea aporta a su carácter dos rasgos característicos de su etnia: el heroísmo ("El alma heroica que heredara de su padre" [ibíd., pág. 102-103]) y una excesiva y peligrosa fantasía ("fogosa y pertinaz imaginación" [ibid., pág. 72]). Estos dos elementos semitas de su personalidad, de los cuales participan todos sus conciudadanos ("su morisca imaginación [de las gentes de la urbe andaluza], ganosa de emociones extraordinarias" [ibíd., pág. $352]$ ), le convierten en un joven que, ya que vive de 1813 a 1840 , irremediable y hereditariamente ha de ser un hombre romántico y àrrastrado hacia la tragedia, al igual que el determinismo de su sangre y de su educación filantrópico-ilustrada llevó a Don Rodrigo Venegas a su muerte.

Si el Niño de la Bola es un "tipo" "costumbrista", ¿cuántos Manuel Venegas no habría en las ciudades andaluzas hacia 1840? Pensemos por un instante. Los convecinos de la "Dolorosa" interpretan, sin serlo, la personalidad de la joven como la de una heroína de novela. ¿No sería que ellos eran los verdaderos caracteres románticos? Después de todo, la sangre de la hija de Don Elías tenía poquísimo de semita (ya que por lo menos su padre era de La Rioja) mientras que a la que sin duda pertenecían los vecinos de Soledad era a la "raza" arábigo-andaluza. A través de su obra, Don Pedro Antonio de Alarcón nos explica que Andalucía (debido especialmente al heroísmo, así como a la imaginación y fantasía, propios de su etnia) fue pasto precioso del Romanticismo. El propio novelista es un buen ejemplo de lo dicho, por lo menos bajo interpretación de sus contemporáneos ${ }^{10}$.

10. Doña Emilia Pardo Bazán, en el folleto que dedicó a nuestro autor (op. cit.), apunta repetidamente la conexión entre la sangre semita de Don Pedro Antonio y su romanticismo y liberalismo juveniles, exaltados primero y calmados en su madurez:

Pero notemos también lo impresionable del temperamento de Alarcón, lo crespo y alborotado de su alma semita (pág. 1366),

pues Alarcón no era revolucionario, ... pero tenía en su alma el calor y la inquietud propios de los hijos del Mediodía... (pág. 1367).

Esta es la primera parte del análisis de la novelista gallega ya que, al igual que Don Pedro Antonio con el Niño de la Bola, ella realiza una completa "fisiognomía" del autor andaluz y, así, junto a su caracterización psicológica, dibuja Doña Emilia la descripción física del literato: 
La reconstrucción "costumbrista" de El Niño de la Bola va más allá. Incluye el otro aspecto del "costumbrismo", el estudio pormenorizado de la economía, la sociedad, las tradiciones religiosas, educativas y literarias, la política, etc. de una urbe provinciana de Sierra Morena en los años próximos a 1840 .

Los personajes de El Niño de la Bola, como "tipos", resumen peculiares "modos de sentir, de soñar, de amar y de creer" de los habitantes de la Sierra, dependiendo de su edad y circunstancias vitales ("raza" y herencia, educación, familia, etc.). Tenemos el joven romántico, librepensador y ateo (Manuel Venegas), la jovencita mimada que todos creen romántica y, en realidad, sería una adúltera y materialista (la "Dolorosa"), tenemos a los hombres maduros educados en la Ilustración (Don Rodrigo Venegas y Don Trajano y sus amigos); frente a la joven provinciana (la "Dolorosa"), presenta Don Pedro Antonio a una forastera (Doña Luisita), exteriormente un ejemplo de romanticismo madrileño, pero en el fondo una materialista empedernida; frente al librepensador y ateo, aunque hombre bueno (Manuel Venegas), existe otro joven de su misma edad, también librepensador y ateo, pero malo por naturaleza ("Vitriolo"); el "cuadro" se perfila con un santo obispo, "un cura de misa y olla" (Alarcón, 1880, pág. 45) representado por Don Trinidad Muley, una simple madre de familia (la señá María Josefa) y miles de "moriscos" y unos pocos "forasteros, procedentes de Santander, de Galicia, de Cataluña o de la Rioja" (ibíd., pág. 32).

Si se analiza El Niño de la Bola desde el punto de vista social, la novela es también un prodigio de reproducción de la economía y de la sociedad de dicha urbe de Sierra Morena en 1840. En el pasado, en tiempos de D. Carlos III (ibid., pág. 96), hubo intentos de explotación de las riquezas de la Sierra; hay en la ciudad algunos "hijosdalgo", unos ricos (el Marqués de Mirabel) y otros que perdieron su riqueza (Don Rodrigo); a estas tierras andaluzas han llegado "forasteros" que se convierten pronto en "todos los dignos comerciantes e industriales de las poblaciones de Andalucía, inclusas las capitales y aldeas" (ibíd., pág. 32), no hay mejores ejemplos de esto que el usurero "Caifás" (Don

Mirábale yo, y de moro le encontraba la figura: con aquella nariz algo curva, aquellos ojos hundidos, de azabache, aquella oriental barba, le sentarían a maravilla el turbante y el alquicel (págs. 1374-1375).

(Quien lea atentamente el capítulo de El Niño de la Bola titulado "Nuestro héroe", se sorprenderá del exacto parecido externo entre Manuel Venegas y su autor).

No sólo la Pardo Bazán reconoce la "raza" semita de Don Pedro Antonio, pues otro de sus contemporáneos, Don Manuel de la Revilla, realiza una "fisiognomía" muchísimo más completa del novelista andaluz (Revilla, 1883, págs. 91-100):

Ostentaba su fisonomía los trazos característicos de aquella generosa raza, y encerraba su espíritu todas las cualidades que la distinguieron: ardiente y soñadora fantasía, condición indómita y arrogante, corazón fogoso e hirviente en pasiones, ánimo dispuesto a todo linaje de temerarias aventuras y poderosos ataques (pág. 92).

(En esta ocasión, obsérvese el parecido psicológico entre el Niño de la Bola y su creador). 
Elías) o el industrial Don Antonio Arregui, padre y marido de Soledad respectivamente; y nos informa también Alarcón de que, en Madrid, cierta marquesita de vida romántica (Doña Luisa) derrocha con este tipo de existencia las últimas tierras que heredó y que se hallan en Sierra Morena; para completar el "cuadro" tenemos un militar en retiro que vive de su pobre pensión, un ayudante de botica ("Vitriolo"), varios secretarios de ayuntamiento, etc.

El estudio de El Niño de la Bola desde su reconstrucción política presenta el poder de la ciudad en manos de un "hijodalgo" rico (Don Trajano Mirabel), socorrido en sus funciones, posiblemente, por la inspiración del obispo de la urbe. Además, desde Madrid, personalidades políticas como Don Evaristo Pérez de Castro ("a la sazón Presidente del Consejo de Ministros" [ibíd., pág. 160]) y Salustino Olózaga (político y orador que vivió de 1805 a 1873 y que fue Presidente del Consejo (1843) y varias veces embajador en París) le mandan al señor de Mirabel cartas recomendándole a Doña Luisita, lo que prueba las buenas relaciones del "cacique" con hombres políticos de la Capital de España.

¿Quién puede negar que El Niño de la Bola no sea una "novela de costumbres"?

La afirmación de este interrogante nos define la novela de Don Pedro Antonio como una obra de la segunda mitad del siglo XIX (a saber, del Realismo/Naturalismo) porque "novela de costumbres" era el nombre utilizado en la época para referirse a Fortunata y Jacinta, Un viaje de novios, Pepita Jiménez, La Regenta, La Montálvez, Pequeñeces, José, y etc., etc., etc. ¿Significa esto que el "costumbrismo" (el segundo pilar -iy básico!- de la novela posterior a La Gloriosa) es privativo de la "novela de costumbres"?

Ni mucho menos, ni tan siquiera del siglo XIX. Las raíces, de nuevo, hay que buscarlas en la Ilustración. Don Pedro Antonio descubre esta verdad histórica (todo el pensamiento decimonono tiene sus bases ideológicas en el Siglo de las Luces) por boca de uno de los amigos ilustrados del señor de Mirabel. Este último está maldiciendo a los románticos, librepensadores y ateos (es decir, a las coordenadas mentales más importantes del siglo XIX) y su amigo le replica:

- ¿Esas gentecilla que dices es nuestra legítima heredera!... Nosotros, con nuestros pergaminos y sangre azul, fuimos, cuando jóvenes, partidarios de la Razón, del Buen Sentido, y hasta de aquel Ser Supremo que substituyó al antiguo Jehová... ¿No te acuerdas? (ibíd., págs. 354-355. Subrayados de Don Pedro Antonio).

Si Don Trajano y sus amigos son discípulos de Moratín, en éste y en Tomás de Iriarte encontramos los mejores ejemplos de "costumbrismo" (descripción realista" + "el estado de la cultura contemporánea") del siglo XVIII. 
De nuevo ha sido Russell P. Sebold quien, en el Prólogo a su edición de $E l$ señorito mimado. La señorita malcriada y en su artículo "Historia clínica de Clara: La mogigata de Moratín", ya citados con anterioridad, desarrolla y explica el "realismo" (avant la lettre) y el estudio de costumbres de estas obras.

Algunos pueden objetarme, sin embargo, que estoy aduciendo textos "costumbristas" que no pertenecen al género de la novela. $O$ decirme que entre el teatro de costumbres contemporáneas del siglo XVIII y la novela posterior a La Gloriosa median más de cincuenta años. Pues bien, justamente en tal intermedio crecieron y se desarrollaron dos grandes manifestaciones "costumbristas", los artículos de costumbres y la novela histórica.

El "costumbrismo" en las colecciones de artículos de Mariano José de Larra, Ramón de Mesonero Romanos o de Serafín Estébanez Calderón no presenta problema alguno, a no ser que se me puede seguir objetando que éste no es un género novelístico.

Si pasamos a la novela histórica del Romanticismo, entonces la objeción es mayor ya que muchos no creerán que sea ésta una modalidad "costumbrista". Sin embargo, lo es, y así lo aceptaron incluso los críticos librepensadores de la segunda mitad del siglo XIX. Armando Palacio valdés, en artículo de 1878 ya citado, "D. Manuel Fernández y González", no sólo sabe que la novela histórica, desde el mismo Walter Scott, es "costumbrista", sino que cree que la elaborada por Fernández y González se caracteriza por un grado superior de "costumbrismo", pues "es más realista de la Edad Media que su maestro Walter Scott" (Palacio Valdés, 1878c, pág. 713. Subrayado del autor). El carácter "más realista" al que alude el crítico responde a que Manuel Fernández y González, frente a Walter Scott, se preocupa por "penetrar más adentro... en el mundo del espíritu" de la Edad Media mientras el novelista inglés se detiene sólo en la reproducción "realista" de sus "costumbres, sus trajes, su fisonomía exterior" (ibid.). Sea como sea, Palacio Valdés reconoce que, ya desde su mismo padre, la novela histórica tenía por finalidad "un estudio atento y minucioso" (ibid.) del escenario externo de un momento puntual de la Historia y que incluso algunos, como es el caso de Manuel Fernández y González, sumaron al análisis de la "fisonomía exterior" de un período pretérito el "cuadro" también "realista" de su particular psicología. Esos "algunos" fueron los menos. Por eso, el mismo Armando Palacio Valdés consideró en su "D. Francisco Navarro Villoslada", utilizado con anterioridad, "que la novela arqueológica no es viable como género literario" (Palacio Valdés, 1878a, pág. 713), y que "las costumbres y los sentimientos que se pinten, han de ser las costumbres y los sentimientos contemporáneos" (ibíd.). Sin embargo, la novela histórica continuó incluso en la segunda mitad del siglo XIX, teniendo como máximo cultivador a Don Benito Pérez Galdós. 
Si la "novela costumbrista" posterior a La Gloriosa es novela de caracteres (es decir, "tipos") y es novela de "costumbres", y la buena "novela arqueológica" ha de saber combinar también ambos rasgos ", ¿en qué se diferencian las dos formas novelísticas del siglo XIX? La clave nos la da Rafael Altamira y Crevea, en artículo titulado "Un drama de Galdós", sobre una adaptación teatral de El audaz: la "novela arqueológica" o histórica es un estudio de caracteres y de costumbres "en una retroacción artística de tiempos pasados" (Altamira y Crevea, 1921, pág. 63). Es decir, la única diferencia entre la novela de la primera mitad del XIX (Romanticismo) y de la segunda (Realismo/ Naturalismo) es que el análisis de "tipos" y "cuadros" tiene lugar, en aquélla, en un marco histórico pretérito, generalmente la Edad Media, mientras que, en la "novela de costumbres (contemporáneas)", la acción acontece en el momento histórico contemporáneo al autor.

Dibujadas así las cosas, el "costumbrismo" es una corriente estética (="realismo") y mental (= a la búsqueda del carácter o psicología de un pueblo o colectividad). Como movimiento, tuvo una larga vida. Recogió sus principios ideológicos y estéticos en la Ilustración, y se plasmó artísticamente en ese mismo siglo, llegando -fiel a sus bases originales- hasta fines de la centuria siguiente.

Volvamos a El Niño de la Bola. Sin lugar a dudas, es una novela "costumbrista". Pero, ¿es una "novela arqueológica", es decir, un estudio de las "costumbres" "en una retroacción artística de tiempos pasados", o es una típica "novela de costumbres (contemporáneas)"?

En 1870 se publicó en Madrid La fontana de oro, de Benito Pérez Galdós. Sobre ella decía José Alcalá Galiano, en Revista de España (1871), que se anunciaba "como novela histórica, y si bien tal título le corresponde por referirse y pintar hechos de nuestra historia de 1820 " asimismo "con no menor fundamento puede calificarse de novela de costumbres" (op. cit., pág. 150. Subrayados míos). Manuel de la Revilla, en su boceto literario sobre "D. Benito Pérez Galdós", aceptaba el mismo hecho en torno a La fontana de oro y El audaz: "Reconocióse lo feliz de la combinación de la novela histórica con la de costumbres" (Revilla, 1883, pág. 112). ¿Significaba esto que novelas como La fontana de oro (1870) o El audaz (1871) y los Episodios participan del mismo género que El doncel de don Enrique el doliente (1834) o El señor de Bembibre (1844)? Sí, aunque entre los dos grupos de novelas existe una pequeña diferencia; en las primeras se abandona "los heroicos tiempos de nuestra reconquista" y "de la dinastía austriaca" (Alcalá Galiano, 1871, pág. 152)

11. Así se desprende de las siguientes palabras de Alcalá Galiano (op. cit., pág. 154. Subrayados míos):

Walter Scott y en general los novelistas ingleses pecan, es verdad, de minuciosos, pero en cambio ¡qué tipos tan acabados, reales y perfectos!, ¡qué cuadros tan inimitables han creado! 
y elige una época intermedia que, sin tener el excesivo y peligroso realismo del momento presente, está lo suficiente remota para inspirar el interés de lo pasado, y bastante inmediata para relacionarse con el presente y pintar la realidad (ibid.)

Es decir, la novela histórica de la segunda mitad del siglo XIX acerca el tiempo de su acción cada vez más a la época contemporánea.

El Niño de la Bola es un ejemplo similar a La fontana de oro, El audaz y los Episodios de Don Benito. Se escribe en 1880, pero en ella Don Pedro Antonio realiza toda una reconstrucción de los "tipos" y "cuadros" de una ciudad andaluza por los años de 1840. La obra de Alarcón es "costumbrista" (porque la novela histórica es un género perteneciente al "costumbrismo"), es también una "novela arqueológica" que tiene por marco una época bastante cercana al momento en que escribe su autor y por este mismo hecho puede adjudicársele también con plena tranquilidad el marbete de "novela de costumbres contemporáneas" ${ }^{2}$ ). En resumen, la historia de Manuel y Soledad reconstruye (en 1880) el universo ideológico y circunstancial de la época romántica (concretamente el del año de 1840) en un ámbito determinado, una ciudad de Sierra Morena.

\section{"Desfaciendo entuertos"}

El presente artículo comenzaba con el planteamiento de un interrogante: ¿es El Niño de la Bola una novela perteneciente al Romanticismo o al Realismo? Sólo podemos responder a esta interrogación clarificando qué es una novela romántica y qué es una novela realista.

Ambas, según lo que llevamos dicho, participan de una misma base ideológico-formal, el "costumbrismo". Por otra parte, éste ha sido definido en nuestras páginas como una técnica "realista" de análisis de caracteres y costumbres ("tipos" y "cuadros") que va en búsqueda de una definición de los "modos de sentir, de soñar, de amar y de creer" de una colectividad, pueblo o "raza". Los hombres de la segunda mitad del siglo XIX, como vimos, intentaron convertir la "novela de costumbres" en privativa de su época llamándola

La novela moderna, la que retrata la sociedad actual y encarna los ideales y sentimientos que a nuestro siglo animan; la que al interés dramático de los sucesos une el interés fisiológico producido por la acabada pintura de los caracteres y el interés social engendrado por los problemas que en ella se plantean; la que sustituye con ventaja a la antigua epopeya y

12. Así lo hizo Juan Valera en su artículo "La poesía lírica y épica en la España del siglo XIX":

Bien puede decirse que Alarcón comparte con Fernán Caballero la gloria de haber resucitado en nuestro país la novela de costumbres contemporáneas... Las dos joyas que me inspiran el anterior elogio son El sombrero de tres picos y El Niño de la Bola (Valera, 1942, pág. 1217). 
representa con pasmosa verdad y brillantes colores la vida compleja y la conciencia agitada de la sociedad presente, no tenía cultivadores en España (Revilla, 1883, pág. 109).

Estos hombres eran conscientes de que la pintura de "tipos" o caracteres y de "cuadros" o costumbres componía básicamente la novela que ellos escribían, pero erraron en creer que estos dos elementos eran una novedad de su época. Ramón de Mesonero Romanos interpretaba, años antes que los anteriores, con una mayor precisión histórica el origen y desarrollo, así como el futuro, de las bases constitutivas de toda novela. En la historia de este género reconocía que "en tres diversas clases puede dividirse la composición que, desde los principios de la literatura, tuvo por objeto reproducir en un cuadro de invención los diversos matices del humano carácter y las vicisitudes de la vida social" (Mesonero Romanos, 1839, pág. 253). A saber, en "la novela fantástica o maravillosa [de caballerías] la novela de costumbres [picaresca y Cervantes] y la histórica o tradicional [Walter Scott]" (ibid. Subrayados del autor) ".3. Mesonero Romanos reconoció que "tipos" y "cuadros" los ha habido siempre en la novela, lo que iba cambiando con el tiempo era el grado de realismo/idealismo de la reproducción (a saber, el mayor o menor nivel de bastardía reconstruyendo la realidad) y era el momento histórico elegido como marco de la obra (la época contemporánea al autor o cualquier período pretérito). Con gran puntería crítica, Don Ramón define ya, ¡en 1839!, lo que debe ser una buena "novela de costumbres" "ha de describir costumbres, ha de desenvolver pasiones, ha de pintar caracteres" [ibíd., pág. 2545]), y cómo esas "costumbres", "pasiones" y "caracteres" pueden convertirse en una buena "novela arqueológica" si se enlazan "naturalmente con los nombres históricos" y "vengan a formar el cuadro general de una época marcada en la historia de cada país" (ibid.). Reflexionando sobre estas citas, queda claro que lo "nuevo" en la novela del XIX fue la consciencia en la reproducción "costumbrista" de la realidad, es decir, en el hecho de que el análisis minucioso-científico de "tipos" y "cuadros" tenía un solo fin, "formar el cuadro general de una época", ya fuera ésta pretérita o presente.

El "Costumbrismo" (reproducción "realista" + "formar el cuadro general de una época") es lo que une la novela de la primera (Romanticismo) y la segunda mitad del siglo XIX (Realismo/Naturalismo). Pero, ¿qué las separa? Yo diría que únicamente un hecho. La "novela de costumbres (contemporáneas)" tiene por marco histórico la historia de la actualidad mientras la "novela arqueológica" se interesa por el pasado nacional.

13. Igual clasificación aceptaba por los mismos años Juan Guillén Buzarán diciendo: "Yo divido las novelas en tres clases: novelas históricas, novelas ficticias y novelas de costumbres" (Guillén Buzarán [1841] 1984, pág. 230. Subrayado del autor). 
El Niño de la Bola justifica literariamente los lazos que unen todo el siglo XIX español con la época ilustrada, representando también un caso limítrofe entre la "novela arqueológica" y la "novela de costumbres" y destruyendo de esta manera el falso muro levantado entre el Romanticismo y el Realismo. El género al que pertenece la obra del novelista andaluz es el primero de los mencionados (novela histórica), sin embargo, haciendo un análisis del período del Romanticismo, tan próximo a la actualidad, coincide con la "novela de costumbres (contemporáneas)" en hallar los ancestros que lo originaron (el Siglo de las Luces) y en vislumbrar las consecuencias que él mismo provocó (a saber, la peculiar psicología del hombre de la segunda mitad del XIX). En suma, El Niño de la Bola es una explicación literaria del puente que existe entre el XVIII y el XIX españoles ${ }^{14} \mathrm{y}$ de la continuidad teleológica entre la primera y la segunda mitad de este último. La novela ayuda pues a "desfacer" uno de los grandes "entuertos" interpretativos de nuestra historia literaria.

\section{BIBLIOGRAFÍA}

ALARCÓN, Pedro A. 1880. El Niño de la Bola, Madrid, Víctor Saiz.

-. 1884. El Niño de la Bola, Madrid, Pérez Dubrull.

ALAS, Leopoldo. 1889. Benito Pérez Galdós. Estudio crítico-biográfico, Madrid, Ricardo $\mathrm{Fe}$.

-. 1981. La Regenta, ed. G. SOBEJANO, 2 vols., Madrid, Castalia.

ALCALÁ GALIANO, José. 1871. "Noticias literarias. La fontana de oro", Revista de España, XX, págs. 148-158.

ALTAMIRA Y CREVEA, Rafael. 1921. "Un drama de Galdós", Arte y Realidad, Barcelona, Cervantes.

BESER, Sergio, ed. 1972. Leopoldo Alas: Teoria y crítica de la novela española, Barcelona, Laia.

GUILLÉN BUZARÁN, Juan. [1841] 1984. "Discurso sobre la influencia de las novelas", La novela aragonesa en el siglo XIX, ed. de R. M" Andrés ALONSO, Zaragoza, Guara, págs. 224-232.

GINER DE LOS RÍOS, Francisco. [1864] 1969 “"De la poesía épica y en particular de la epopeya", Ensayos, ed. J. LOPEZ-MORILLAS, Madrid, Alianza, págs. 53-63.

IRIARTE, Tomás de. 1986. El señorito mimado. La señorita malcriada, ed. R. P. SEBOLD, Madrid, Castalia.

ISLA, José Fco. de. 1960-1964. Fray Gerundio de Campazas, ed. R. P. SEBOLD, 4 vols. Madrid, Espasa-Calpe.

MESONERO ROMANOS, Ramón de. 1839. "La novela", Semanario Pintoresco Español I, págs. 253-255.

$14 \mathrm{Al}$ igual, por ejemplo, que El audaz de Don Benito Pérez Galdós. 
MONTESINOS, José F. 1960. Costumbrismo y novela, Berkeley-Los Angeles University of California Press.

NAVARRETE, Ramón de. 1847. "La novela española", Semanario Pintoresco Español XII, págs. 82-84, 117-119 y 130-131.

PALACIO VALDÉS, Armando. 1878a. "Los novelistas españoles. D. Francisco Navarro Villoslada", Revista Europea, núm. 22, págs. 712-714.

-. 1878b. "Los novelistas españoles. D. Benito Pérez Galdós", Revista Europea, núm. 212, págs. 335-339 y núm. 214, págs. 400-405.

—. 1878c. "Los novelistas españoles. D. Manuel Fernández y González", Revista Europea, núm. 222, págs. 659-663.

PARDO BAZÁN, Emilia. 1973, Cuentos. Crítica literaria (selección), tomo III de las Obras completas, Madrid, Aguilar.

PÉREZ GALDÓS, Benito. 1870, “Observaciones sobre la novela contemporánea en España. Proverbios ejemplares y proverbios cómicos, por Ventura Ruiz Aguilera”, Revista de España XV, núm. 57, págs. 162-172.

—. [1897] 1972. "La sociedad presente como materia novelable" y "José María de Pereda, escritor" Ensayos de crítica literaria, ed. L. BONET, Barcelona, Península, págs. $173-182$ y $189-204$.

REVILLA, Manuel de la. 1883. "D. Pedro Antonio de Alarcón” y "D. Benito Pérez Galdós”, Obras de..., Madrid, Víctor Saiz, págs. 91-100 y 109-116.

SEBOLD, Russell P. 1977. "Historia clínica de Clara: La mogigata de Moratín", Estudios ofrecidos a Emilio Alarcos Llorach, 2 vol., Oviedo, Servicio de Publicaciones de la Universidad de Oviedo, vol II.

-. 1988. "El duque de Rivas, novelista", $A B C, 16-4-1988$, pág. 72.

TYTLER, Graeme. 1982. Physiognomy in the European Novel. Faces and Fortunes, Princeton, Princeton UP.

VALERA, Juan. 1942. Crítica literaria. Estudios críticos. Historia y política. Miscelánea, vol II de Obras completas, Madrid, Aguilar.

VIDART, Luis. 1882. "El naturalismo en el arte literario y la novela de costumbres. Un viaje de novios, por Emilia Pardo Bazán. Madrid, 1881", Revista de España LXXXV, núm. 338, págs. 181-197. 